\title{
Research
}

\section{Adaptive Comanagement in the Venice Lagoon? An Analysis of Current Water and Environmental Management Practices and Prospects for Change}

\author{
Stefania Munaretto $^{1,2}$ and Dave Huitema $^{2}$
}

\begin{abstract}
Adaptive comanagement (ACM) is often suggested as a way of handling the modern challenges of environmental governance, which include uncertainty and complexity. ACM is a novel combination of the learning dimension of adaptive management and the linkage dimension of comanagement. As has been suggested, there is a need for more insight on enabling policy environments for ACM success and failure. Picking up on this agenda we provide a case study of the world famous Venice lagoon in Italy. We address the following questions: first, to what extent are four institutional prescriptions typically associated with ACM currently practiced in the Venice system? Second, to what extent is learning taking place in the Venice system? Third, how is learning related to the implementation or nonimplementation of the prescriptions of ACM in the Venice system?
\end{abstract}

Our analysis is based on interviews with stakeholders, participatory observation, and archive data. This paper demonstrates that the prescriptions of ACM are hardly followed in the Venice lagoon, but some levels of cognitive learning do take place, albeit very much within established management paradigms. Normative and relational learning are much rarer and when they do occur, they seem to have a relatively opportunistic reason. We propose that in particular the low levels of collaboration, because the governance system was deliberately set up in a hierarchical and mono-centric way, and the limited possibilities for stakeholder participation are implicated in this finding because they cause low levels of social capital and an incapacity to handle disagreements and uncertainty very well.

Key Words: adaptiveness; comanagement; governance; institutions; learning; Venice lagoon

\section{INTRODUCTION}

These days it is hard to find anyone disagreeing with the notion that social-ecological systems (Berkes and Folke 1998) exhibit many "wicked" traits such as nonreducibility, spontaneity, and variability (Dryzek 1987). Those wanting to manage such systems face surprise, unpredictability, and the possibility of unexpected "tipping points." The literature on adaptive management (Gunderson and Holling 2002) and comanagement (e.g., Wondolleck and Yaffee 2000) speak to these challenges and these two bodies of literature are currently seen as converging into a literature on adaptive comanagement (ACM; Olsson et al. 2004, Armitage et al. 2007). Adaptive management emphasizes learning and uses structured experimentation in combination with flexibility as ways to achieve this. Comanagement emphasizes the sharing of rights, responsibilities, and power between different levels and sectors of government and civil society. ACM, then, is a novel combination of the learning dimension of adaptive management and the linkage dimension of comanagement (Olsson et al. 2004, Armitage et al. 2007). The literature on ACM typically suggests four institutional prescriptions should be followed to enhance adaptability: polycentricity, participation, experimentation, and bioregional approach (Lee 1999, Huitema et al. 2009).
ACM is attractive as an idea but very hard to introduce and sustain in practice (Lee 1999). One could ask questions about what holds back the introduction of ACM in real life settings, but also analyze the consequences of nonimplementation. In this vein, we follow Armitage et al. (2007:6-10), who pointed to the need to move beyond "the limits" of ACM, and suggest "policy implications" as a key theme for research, pointing to the need for more insight on enabling policy environments and "conditions of ACM success and failure." Questions to be answered under these headings relate to ways to establish cross-level linkages, the conditions for partnerships that really share power, and ways to move from cognitive to normative learning.

We attempt to bring the discussion about the feasibility and efficacy of the ACM institutional prescriptions further. However, just assessing the ongoing efforts does not suffice. Furthering the analytical agenda related to ACM also requires understanding about the consequences of the implementation or nonimplementation of the prescriptions in terms of the key goal of learning. This is one aspect of what ACM seeks to accomplish because the approach also emphasizes flexibility and reversibility in infrastructural measures. We feel such a restricted focus is warranted because learning logically precedes course reversals, or the dismantling of flexible

${ }^{1}$ University IUAV of Venice, Faculty of Urban and Regional Planning, Venice, Italy, ${ }^{2}$ VU University - Institute for Environmental Studies (IVM), Amsterdam, Netherlands 
infrastructures. To analyze learning, we apply the typology, i.e., cognitive, normative, and relational learning, that was described in this journal by Huitema et al. (2010). Therefore, we answer three questions, centered on the management of the Venice lagoon in Italy:

- To what extent are the four institutional prescriptions typically associated with ACM currently followed in the Venice system?

- To what extent is learning taking place in the Venice system?

- How is learning related to the implementation or nonimplementation of the prescriptions?

We describe our theoretical framework, our methodology, and the social-ecological context of our case study. We apply the ACM prescriptions as a normative framework for assessing the ongoing water and environmental management efforts at safeguarding the Venice lagoon. In so doing, we provide a critique of the current safeguarding measures that are being implemented in this world famous city. We analyze the level of learning and relate it to the prescriptions in the subsequent four sessions. We conclude this article by discussing our findings and providing several suggestions for improving the management system so as to increase the possibilities for learning.

\section{THEORETICAL FRAMEWORK}

We briefly illustrate the four institutional prescriptions typically associated with ACM, the concept of learning and learning typologies. Because the arguments we are making are based on articles already published in this journal (see Huitema et al. 2009, 2010) we will be succinct and the reader who is interested in a full explanation, including for instance a discussion of the advantages and disadvantages of the four prescriptions, is referred to these earlier publications.

The first ACM prescription revolves around polycentricity. Polycentric governance systems are defined as systems in which "political authority is dispersed to separately constituted bodies with overlapping jurisdictions that do not stand in hierarchical relationship to each other" (Skelcher 2005:89). The literature on polycentric governance initially focused on the importance of local self-control, making governance fit with local political preferences (e.g., Ostrom et al. 1961). More recent literature (e.g., Dietz et al. 2003, Karkkainen 2004, Ostrom 2005) suggests that polycentric governance systems are more resilient and better able to cope with change and uncertainty. The reasons for this are, first, that issues with different geographical scopes can be managed at different scales. Second, polycentric systems have a high degree of overlap and redundancy, and this makes them less vulnerable: if one unit fails, others may take over their functions (see e.g., Granovetter 1983, Perrow 1999). Finally, the large number of units makes it possible to experiment with new approaches so that the units can have the opportunity to learn from each other (Ostrom 2005).

The second prescription relates to public participation. We define public participation as the taking part, by ordinary citizens or their collectives, in the processes of government and/or governance; we refer to situations in which a substantial number of citizens play a part in the process by which leaders are chosen and policies are shaped and implemented. Public participation is expected to contribute to a better understanding of the social-ecological system, because all relevant sources of information are used with greater reflexivity, as actors learn to understand how others see the issues. This results in increased legitimacy and support for decisions taken, because actors are less likely to oppose decisions they have made themselves, and in greater accountability and transparency, because decisions need to be publicly explained and motivated (see e.g., Coenen et al. 1998, Huitema 2002, Ridder et al. 2005, Mostert et al. 2007).

The third institutional prescription, experimentation, is about planned interventions in the social-ecological system and the monitoring of their results to learn about ecosystems functioning while managing (e.g., Walters and Holling 1990, Lee 1999, Richter et al. 2003). Any intervention or policy can be seen as an experiment, a way of testing hypotheses (e.g., Walters 1997, Pahl-Wostl 2006) and an opportunity for learning by doing. In the policy sciences, experimentation is seen as a methodology for factual learning, but the prospects for more reflexive forms of learning are deemed to be dimmer (see e.g., Fischer 1995, Greenberg et al. 2003). Some authors, however, suggest that experiments can function as "boundary objects" for bringing in multiple stakeholders (Huitema and Turnhout 2009). Even when an experiment might have only a factual learning agenda, greater reflexiveness might be an additional effect because those involved in the experiment can improve network relations through repeated interactions and the emergence of trust (Lejano and Ingram 2009). This in turn is expected to increase their capacity to deal with uncertainty and change (e.g., Moberg and Galaz 2005).

The fourth prescription of ACM is to organize management at the bioregional level such as a river basin, also when such a bioregion crosses administrative boundaries. Among governance scholars, the creation of institutions at the appropriate scale is discussed as a matter of "optimization" (Gibson et al. 1998) or "fit" and "interplay" (Young 2002). The arguments speaking in favor of the creation of a bioregional approach are mainly related to the perceived failures of existing resource management institutions. These include lack of recognition of ecological interdependencies between ecological processes at multiple scales; lack of cooperation between institutions; lack of transparency, making the institutional structure difficult to understand for outsiders and thereby limiting public participation; 
overlooking of problems that do not fit in established programs; and finally, the existence of a lax management setting in which special interests such as farmers and industry can dominate (Schlager and Blomquist 2000 describe these issues for river basin organizations). Institutions at the ecosystem level are supposed to address these.

In this article we are interested in the learning that is taking place in the Venice lagoon governance system. One of the key activities of the governance system is the production of policies that will steer its interventions in the ecosystem. Thus, we are interested in policy learning, which we can define as "relatively enduring alterations of thought or behavioral intentions that result from experience and that are concerned with the attainment (or revision) of public policy" (Sabatier 1998:104; for a more elaborate discussion see Huitema et al. 2010 and Haug et al. 2011).

Within the literature three critical aspects of learning have been identified, namely: who learns, what is learned, and to what effect? (Bennett and Howlett 1992). The literature is fairly imprecise over what exactly is meant by these three aspects. However, they provide a useful framework around which we can understand how learning in an appraisal process may lead to more reflexive critiques of policy goals.

As to the question of who learns, the basic distinction is between policy makers and societal actors. Some authors, such as Hall (1993), largely focus on the lessons that policy makers draw from their experiences, whereas others have shown greater interest in the way in which groups of societal actors, such as "advocacy coalitions" (Sabatier 1988) or "epistemic communities" (Haas 1992), learn, whether in interaction with policy makers or not. Obviously, the way the general public learns about policies is also relevant, but this is the topic of a different literature, the literature on agenda formation and agenda setting (see Wanta 1997, McCombs 2005).

As for what is being learned, most writing on policy learning distinguishes between different types and different degrees of learning (see Swartling and Nilsson 2007). Regarding the types of lessons learned, Webler et al. (1995) suggest that there is a difference between the "cognitive enhancement" of parties, i.e., the acquisition of knowledge, and their "moral development," i.e., how individuals come to be able to make judgments about right and wrong. Others have pointed to the importance of what we may refer to as relational learning. This type of learning relates to issues such as trust building, changes in the ability to collaborate, and changes in the ability to understand another party's goals and preferences (see e.g., Imperial and Hennessey 1999, Imperial 2005; Table 1).

As for what effect policy learning is intended, the overview of Bennett and Howlett (1992) suggests that most authors associate policy learning with policy change, in the sense that they only want to speak of policy learning in cases where policies have been modified or new policies have been adopted. In our opinion, this is a dubious assumption, for two reasons. The first is that policy change is often a result of other factors than policy learning. One can think of changes in government, bargaining between parties in the policy process, the emergence of powerful lobby groups, etc. Second, even if policy learning does occur, it does not always express itself in the form of policy change, but may equally result in a better foundation for existing policies. This could also be seen as a form of policy learning, because the evidence base for the current policy would have increased in such a case.

Table 1. Types of policy learning measured.

\begin{tabular}{ll}
\hline Typology of policy learning \\
\hline Cognitive & Factual learning without changing underlying \\
learning & norms, values, belief systems \\
Normative & Learning encompassing a change in norms, values, \\
learning & and belief systems \\
Relational & $\begin{array}{l}\text { Enhanced trust, improved understanding of } \\
\text { learning }\end{array}$ \\
\hline
\end{tabular}

\section{DATA AND METHODOLOGICAL APPROACH}

The empirical findings presented in this article are based on secondary analysis of scientific accounts (e.g., Dente et al. 2001, Giupponi et al. 2001); and archive analysis of legal and policy documents, assessment and thematic reports, and local newspaper articles between 2004 and 2011 (e.g., Il Gazzettino, Il Corriere del Veneto). We also have held 16 semistructured interviews with key policy makers and stakeholders in the Venetian basin between March and June 2010.

All interviewees had extensive knowledge about the safeguarding of the Venice lagoon and in particular on water and environmental management. They were selected on the basis of their working position and their expertise, and their views on the safeguarding of Venice. We asked questions about options and challenges for the safeguarding of Venice, effectiveness and the impacts of the existing institutional arrangements, visions for the future of Venice, and policy needs to reform the current institutional system. The interviewees requested to remain anonymous and therefore their names are not reported here.

By analyzing this material we gained understanding about actors' perspectives, their networks and coalitions, authority and power relations, informal rules, and discourses on the safeguarding of Venice and their evolution in time. The interpretation of the data was facilitated by the fact that the first author has firsthand experience on the functioning of the Venice system, having worked for seven years in the role of member of the technical secretariat of the Ufficio di Piano (UdP), a technical committee advising the national 
government on priorities for safeguarding Venice and its lagoon. She was involved in the preparation of and attended all 72 UdP meetings from 2004 to 2011 . Most information connected with these meetings (minutes, notes, presentations) is confidential; however the UdP released a number of documents that are available at: www.magisacque.it/uff piano/ uff piano.htm. The involvement of the first author in meetings of the UdP may have introduced a bias toward either favoring or disfavoring the outcome. However, we think our perspective goes beyond the policy dominated views of the administrations and the government because the UdP is a technical advisory committee that gained information from all different public and private organizations in charge of safeguarding the Venice lagoon.

\section{THE VENICE LAGOON SOCIAL-ECOLOGICAL SYSTEM}

The Venice lagoon is the largest coastal lagoon of the Mediterranean region. About $60 \mathrm{~km}^{2}$ of sand strips interrupted by three inlets separate the lagoon from the North Adriatic Sea. An intricate network of rivers, streams, and artificial channels spanning on about $2000 \mathrm{~km}^{2}$ of catchment basin ensure the inflow of freshwater into the lagoon through several estuaries. About $87 \%$ of the total $550 \mathrm{~km}^{2}$ lagoon surface is open to the tide, with the closed surfaces occupied by fish farming. Land covers about $8 \%$ of the lagoon and is spread over more than one hundred islands, coastal strips, reclaimed land, and banks (Fig. 1). The lagoon ecosystems are diverse, including typical coastal and marine environments, i.e., beaches and dunes at the littorals; brackish environments, i.e., salt marshes, mud flats, and shallows in the lagoon basin; and fresh water environments along waterways and rivers estuaries flowing into the lagoon.

The UNESCO World Heritage historical city of Venice is located at the heart of the lagoon. The population of the islands has been declining from 170,000 inhabitants in the $1950 \mathrm{~s}$ down to 90,000 at present. Inhabitants mostly moved to the nearby mainland. The 2000 ha chemical and petrochemical industrial area of Porto Marghera (Fig. 1) is nowadays heavily contaminated. Some industrial plants have been abandoned and a cleaning-up plan is being implemented under the responsibility of the Ministry of the Environment. Outside the cities, agriculture is the prevailing use of land in the lagoon catchments basin.

Humans, water, and nature are profoundly interrelated in the lagoon. Morphological instability and water level variation represent the two major threats for the physical survival of the lagoon. The diversion of the major rivers, the reconfiguration of the inlets' morphology, the excavation of navigation channels, along with wave motion and modern clam harvesting techniques have caused severe erosion, loss of typical habitats and biodiversity, and the progressive transformation of the lagoon into a marine environment.
Water level variation in the lagoon is a phenomenon driven by tides and storm surges. Because of natural and human induced subsidence and sea-level rise, frequency of floods has dramatically increased over the last 60 years with peaks of 10-12 events in a year over the last decade. At present, climate change is considered one of the possible major drivers of future alteration of the lagoon ecosystem and of more frequent floods in the city of Venice.

Fig. 1. The Venice lagoon, its catchment basin, and the nearshore sea for planning and management purposes according to the Special Law (Source: Regione del Veneto Agenzia Regionale per la Protezione e Prevenzione Ambientale del Veneto [ARPAV]).

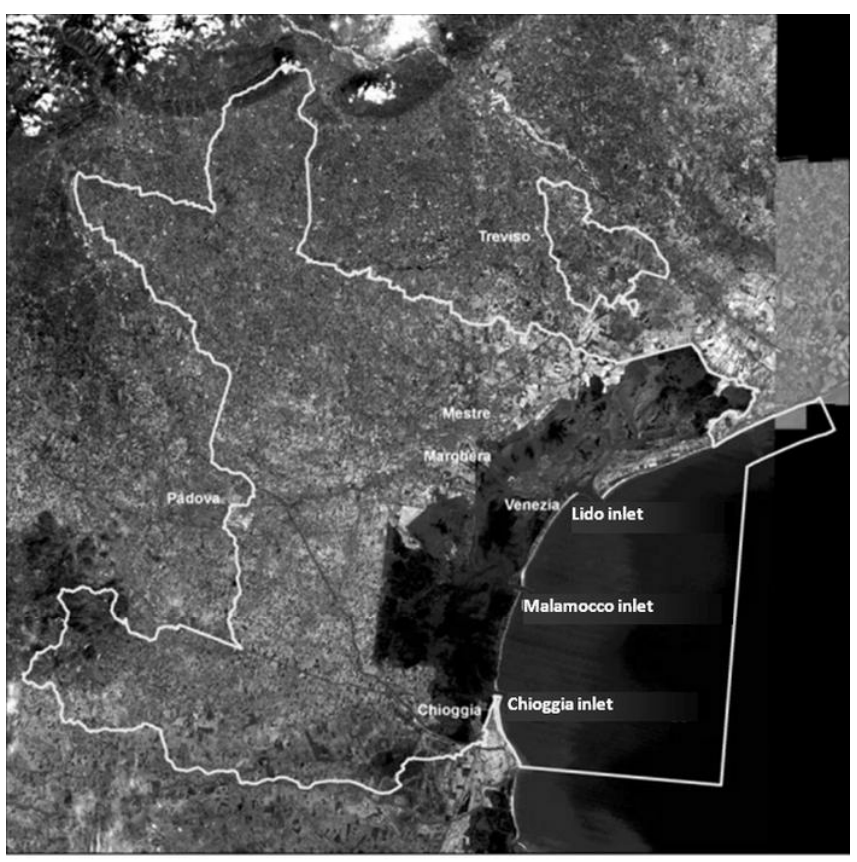

National and local governments started to systematically address the safeguarding of Venice and its lagoon in the early 1970s. At that time the Italian government established a specific legislative regime known as the Special Law for Venice (Fig. 2). The regime set objectives, responsibilities, instruments, measures, and financial resources for carrying out safeguarding activities. Major goals were the protection of urban centers from floods, the protection of coastal strips from erosion and sea storms, the re-establishment of the hydrogeo-morphological equilibrium of the lagoon, the abatement of water pollution both in the catchment basin and the lagoon basin, and the promotion of socioeconomic development of the Venice area. An integrated system of storm surge barriers at the inlets and local defenses, i.e., raising public pavements and restoring banks, to protect the urban centers from floods are two major infrastructural works under construction. 
Fig. 2. Institutional setting established by the Special Law for Venice and other related regulations. Legend: L. = Law; R. L. = Regional Law; DPCM = Decree of the President of the Council of Ministers; Acc.Prog. = Interinstitutional Agreement (Source: Based on the Special Law for Venice, Government and Ministerial decrees, Veneto Region, and local administration regulations and laws).

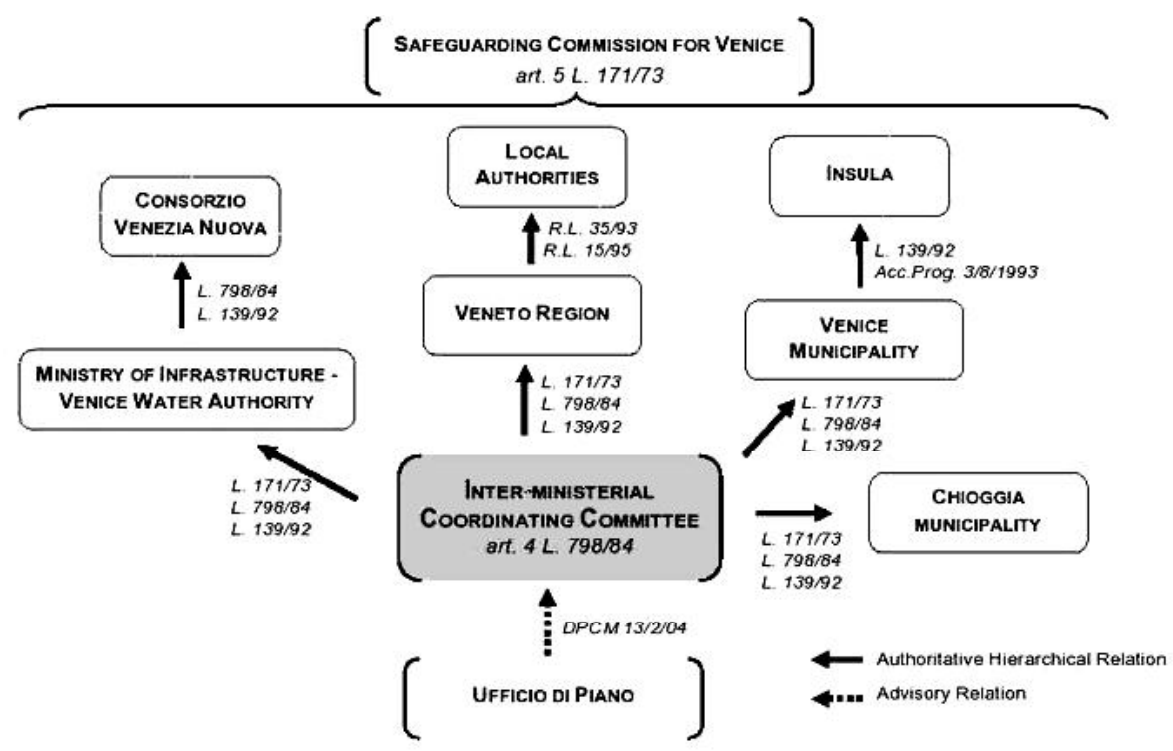

At the national level, the Ministry of Infrastructure is involved in the management of the lagoon through its local branch, the Venice Water Authority. Dealing with water management and navigation control in the lagoon since 1907, the Authority is also in charge of the planning and execution of major safeguarding works. Works are carried out by a private concessionaire of the Ministry of Infrastructure, called Consorzio Venezia Nuova (CVN). The CVN is building the storm surge barriers, the local defenses, and the coastal defenses. It also implements a plan for morphological restoration including reconstruction of morphological structures and natural habitats and provides for the scientific basis for it.

The Special Law implies that the Veneto Region, the Venice and Chioggia municipalities, and the Safeguarding Commission for Venice are involved in the management of the lagoon. The Veneto Region is in charge of abating water pollution in the lagoon catchment basin by allocating funds to local authorities, e.g., municipalities and water bodies. The Venice and Chioggia municipalities are in charge of the maintenance of historical, cultural, architectural heritage and of supporting local socioeconomic development, partly through ad hoc constituted municipal companies. Finally, the Safeguarding Commission for Venice expresses its binding advice to project developers and approving authorities on all building works and territorial transformation planned.

From 1984 to 2010 the government allocated about 10.3 billion Euros to achieve the safeguarding objectives, of which
9.6 billion Euros have already been spent (Ufficio di Piano 2010). Decisions about major safeguarding works and allocation of funds are made by an interministerial committee (Comitatone) in which the regional and local governments are also represented. Since 2004, the Comitatone has been supported by the Ufficio di Piano, a technical committee of national and international experts, and national, regional, and local policy makers.

Alongside the Special Law regime, regional water boards were established in the early 1990s. These organizations will soon be replaced by river basin management authorities recently established under the EU Water Framework Directive. All these changes have so far left the Venice Water Authority responsibilities untouched.

\section{IMPLEMENTING ADAPTIVE COMANAGEMENT IN THE VENICE LAGOON: POLYCENTRIC INSTITUTIONS?}

The complex division of responsibilities and the extensive set of public and semipublic authorities involved in the management of the Venice lagoon suggest that the system indeed exhibits a certain degree of polycentricity in the sense that power is shared among many actors with overlapping responsibilities. However, power is unevenly distributed among key actors and cooperation is limited. Our interviewees suggest that the Venice Water Authority, which is a national agency, and its concessionaire, the CVN, are excessively influential actors in the system and that a hierarchical approach to decisions and lack of trust stemming from unresolved 
institutional disputes have led to a breakdown of cooperation among public actors.

Orchestrating all institutions in the system requires a lot of collaboration, which is difficult to accomplish because governments have different levels of influence on decisions. The Venice Water Authority and its concessionaire successfully network within the national government but do not see fit to link with the local authorities and the community. Having a direct relationship with the national government contributed to a neglect of the need to create local support for national decisions. In reaction to that, local authorities, particularly the Venice Municipality and several environmental groups, developed an opposing and sometimes ideological attitude toward most national decisions, the Venice Water Authority, and the CVN (S. Munaretto, interviews: national agency officers, practitioners, June 2010). Cooperation requires a culture of willingness to work together. The culture of the Italian government is, however, very different. Every government agency is out to assert its leadership and seeks to streamline decision procedures in such a way that other actors are essentially overridden (Keating 1997, Mack Smith 1997, Huysseune 2003). The idea of a hierarchical approach is embedded even more strongly in the Venice lagoon because it is a unique case in Italy in which a national governmental agency (the Venice Water Authority) still has water management responsibilities whereas in the rest of the country they have been passed to the regions. However, the Veneto Region has water management responsibilities in the entire surrounding territory of the lagoon, and challenges the national control. In its turn, the municipality of Venice calls for greater freedom to decide safeguarding policies over its territory. The overall effect of this competition for control is that cooperation becomes very difficult. Interinstitutional agreements, by which costs of works are shared and official procedures simplified, are the vehicle for formally arranging the collaboration between government actors but the few agreements that have been reached required very long and painstaking negotiations.

\section{IMPLEMENTING ADAPTIVE COMANAGEMENT IN THE VENICE LAGOON: PUBLIC PARTICIPATION?}

There is no tradition of public participation and the decision making culture in the lagoon is not favorable to it (Dente et al. 2001, Giupponi et al. 2001). Despite some progress in encouraging public involvement in decision making, also in fulfillment of EU requirements, past experiences did not produce successful outcomes in the sense that either the participative processes were not completed fully, or feedback was not provided to the participants. In both cases the result was that people felt frustrated and lost motivation in the participative processes (S. Munaretto, interview: scientist, June 2010). Findings of Dente et al. (2001) indicate that the public consultation process on Venice issues is dominated by environmental groups, mostly being those people who engage in participative processes. This is a pity because other societal actors also have a high level of awareness of local issues and their participation in management decisions could be beneficial for understanding functioning and problems of the Venice social-ecological system and finding solutions.

Although in principle open to all relevant stakeholders, public participation regarding the safeguarding of Venice remains at the level of what Arnstein (1969) calls "tokenism." This is because participatory forums are hardly organized and most arguments brought forward by participants are commonly ignored. The ongoing discussion about the Special Law may serve as an example. In 2010 the national government appointed the Minister of Public Administration and Innovation to consider options for reforming the law. The Minister organized two meetings with governments and societal organizations, invited written comments from both of them, and launched a web forum to discuss the issue. When a group of citizens and environmentalists wanted to attend one of the presentations the minister was giving to the institutional stakeholders, they were denied access with the argument that the meeting was only for the authorities (Mencini 2010). Having no opportunities for further comments, the societal stakeholders turned to the media to express their opinions. Thus, while "informing" and "consulting" took place, followups or further information were not provided and it is not clear how and to what extent the different contributions were considered in the draft law. The fact that opportunities for interaction, representation, and dialogue are so limited has a sad consequence in that a number of disagreements about decisions turn into conflicts and are subsequently brought to the courts. The case of the storm surge barriers is emblematic of the described situation. During the years, environmental groups, who are in fact often joined by the municipality of Venice, have brought nine appeals, all rejected, against the construction of the barriers to the Administrative Regional Tribunal (TAR) and the Council of State. In 2005, after WWF and other environmental groups claimed violation of the Bird and Habitat Directives (79/409/CEE and 92/43/CEE), the European Commission initiated an infraction procedure against Italy on this case because it agreed that the measures to prevent deterioration of the EU protected habitats were indeed not sufficient. The case was settled in 2009 after the Italian government committed to fund a plan of compensation measures and accepted that an independent party would be monitoring the works. For environmentalists, bringing the case to court was the only chance to prevent the barriers from being constructed.

\section{IMPLEMENTING ADAPTIVE COMANAGEMENT IN THE VENICE LAGOON: EXPERIMENTATION?}

The third prescription we are interested in is experimentation. Numerous research experiments mostly confined to biophysical domains such as water, ecosystems, and related 
technical and technological studies provide scientific basis for environmental management in the Venice system. However, the interpretation and use of knowledge is often questioned and politicized. As for policies, there is very limited willingness to evaluate and change them.

The morphological restoration and the reuse of dredged sediment in the lagoon are key examples of experiments leading to new scientific knowledge and in the case of the morphological reconstructions also to improved environmental management practices. In over 15 years of morphological reconstructions, the Venice Water Authority has developed extensive technical and scientific knowledge that has been used to update the 1993 morphological restoration plan. The result is a new plan, to be finalized in 2012, that adopts a more ecological perspective in the reconstruction of morphological structures than the previous one. The Venice Water Authority also conducted several experiments to test the possibility of safely using lightly polluted dredged sediment for the morphological reconstructions. Unlike the morphological plan case, evidence that using this sediment can be considered safe has not led to alterations in management practices yet. This is because the involved authorities cannot agree on procedures for revising the current agreement on environmental safety criteria for the excavation, transportation, and reuse of dredged sediment.

The Special Law is the foremost example of the difficulty of thinking of policies as experiments and consequently adjusting them according to the level of attainment of the outcomes. The establishment of the Special Law for Venice is the biggest intervention made in the system in past decades. The underlying philosophy is steeped in a hierarchical government tradition, assigning great responsibilities to experts. Ideally, the Special Law itself would be evaluated occasionally from a range of perspectives, generally environmental and economic. The closest example to a policy evaluation is the study of Dente et al. (2001), which suggests that the centralistic government system set by the Special Law has substantially failed. This is mostly because the interministerial committee has limited its activity to irregular meetings for allocating financial resources to the local governments and making decisions on major safeguarding works instead of taking coordinating functions. However, the current process of reforming the Special Law is based neither on such ideas nor on any other systematic evaluation.

\section{IMPLEMENTING ADAPTIVE COMANAGEMENT IN THE VENICE LAGOON: A BIOREGIONAL APPROACH?}

The first attempt to adopt a bioregional approach in the water management sector in Venice dates back to the 16th century. At that time the Republic of Venice established the Venice Water Authority with water management responsibility over a broad territory spanning from the Alps to the lagoon to ensure hydraulic safety and maintenance of navigation in the lagoon. After the end of the Republic in 1797, the Venice Water Authority saw its responsibilities and territory changed several times. In 1907, it was finally re-established as local agency of the Ministry of Infrastructure with water management responsibilities over the lagoon and the watersheds related to its hydraulics. The Venice Water Authority lost its river management responsibilities to the regional level as consequence of a decentralization policy in the 1980s. At present its jurisdiction is limited to the lagoon basin and some other areas outside. According to Rusconi (2002) the Venice Water Authority, in its old configuration, was a good example of the river basin management approach, creating higher levels of hydraulic safety than the current setup.

With the advent of the water boards and the European Water Framework Directive, the concept of management at a river basin scale entered or re-entered Italian public law. However, the water board does not have formal decision making power over the lagoon, which is still under the jurisdiction of the Venice Water Authority, and the establishment of a Venetian subdistrict spanning the lagoon, the catchment basin, and the nearshore sea is hindered by issues of leadership, authority, tasks, and debates about responsibilities.

\section{COGNITIVE LEARNING IN THE VENICE SYSTEM}

Cognitive learning in the Venice management system is confined mostly to the scientific community, and is aimed at furthering predetermined solutions. Large investments of national, regional, and local governments in scientific research have led to improved environmental management practices, e.g., the morphological restoration. There is, however, a tendency to focus research on issues related to the building of large-scale infrastructure such as the storm surge barriers. Specialized experts, most commonly engineers with years of field experience, have come to cover many high-level decision making positions in the field of water and environment management at all levels of government. The general public and part of the scientific community in Venice perceive their approach to environmental management to be too technically oriented and lacking an interdisciplinary perspective necessary to integrate the ecological and the social dimensions of the lagoon system (S. Munaretto, interviews: practitioners, scientists, April 2010). In addition, some local scientists question much of the scientific knowledge on the Venice system produced by the engineers of the $\mathrm{CVN}$, e.g., mathematical models of the lagoon, arguing that it is functional to the infrastructural works and therefore far from being comprehensive and fully objective (S. Munaretto, interview: scientists, April 2010).

Unfortunately, the cognitive learning that occurs within the expert community does not always cross over to other groups, mostly because access to new findings is kept restricted. 
Scientists and policy makers are generally not open to share knowledge with the public either because there is no culture of participation or because they want to avoid long discussions. Lack of resources also limits opportunity for members of the public to develop their own base of knowledge, although increasingly, citizen collectives are organizing with the purpose of gathering scientific information on the functioning of the lagoon ecosystem (S. Munaretto, interview: scientist, April 2010). With some imagination, these citizens could link up with local scientists to form a "shadow network" (Olsson et al. 2006, Meijerink and Huitema 2010) and develop alternative conceptions of management.

\section{NORMATIVE LEARNING IN THE VENICE SYSTEM}

We found little normative learning within the three groups. Within the scientific community some scientists we interviewed claimed that the new morphological plan does not challenge the old management approach even though a broad group of scientists was involved. Discussion on this issue was not possible because the whole process of knowledge generation was controlled and results had to be processed and approved before being shared (S. Munaretto, interview: scientists, April 2010).

Among policy makers it looks like old solutions are revived more often than new ideas are developed. Now that the discussion about the most controversial infrastructure, i.e., the storm surge barriers, has come to a resolution, the Venice Water Authority and the Venice Municipality have started changing perspectives about the safeguarding of Venice. In recent times, they have started suggesting in the media that two of the three goals of the Special Law can be considered achieved because most hydraulic infrastructures are either completed or under construction and the environmental protection is in progress although there are some delays. Conversely, interventions to support the local economy have been inadequate to achieve the third goal of the law, i.e., socioeconomic development, and need to be redefined. They now push for a new agenda that includes the construction of new large-scale infrastructure, an off-shore petrochemical and container-ship harbor. However, this cannot be considered normative learning. Rather it is an attempt to apply the same type of solution, the building of massive infrastructure, to solve several problems simultaneously.

For the public, normative learning seems limited by the culture of going to the courts to solve disputes. By going to court these people show an unwillingness to question their values and their reasons. They are also not engaging in a constructive discussion because in court evidence is distorted or selectively presented. More evidence of the dearth of normative learning is demonstrated by the fact that some environmentalists still call for suspending the construction of the barriers and revising the project (Italia Nostra, www.itali anostra-venezia.org/).

\section{RELATIONAL LEARNING IN THE VENICE SYSTEM}

As for relational learning, we see that reciprocal trust and understanding do not improve and networks do not evolve that much across the three groups. Some of the reasons for this are that scientific knowledge is not fully shared, the governmental system is rather stable and not much open to new people, and court cases annihilate trust among actors.

One reason for limited collaborative networks and trust within the scientific community is that some scientists still oppose the partially finished storm surge barriers. This failure to accept what has become reality hinders a constructive discussion on the future management of this infrastructure. The fact that scientific knowledge does not flow freely in the system also does not help relational learning. In this regard, the updating of the morphological plan was a missed opportunity for the scientists involved to understand each other's knowledge (S. Munaretto, interviews: scientists, practitioners, April 2010).

The Special Law has shaped networks and coalitions in the field of water and environmental management for more than 30 years. Over a decade of political and administrative stability gave policy makers time to develop and consolidate networks with the scientific community and societal actors, and to build institutional memory. When several policy makers either retired or were replaced between 2009 and 2010, institutional memory suddenly disappeared and a window of opportunity opened for new people to enter the system and develop novel coalitions and networks. However, what happened appears to have been a game of musical chairs because a number of these policy makers had a new position in other local public organizations and people coming from other societal groups such as NGOs remained excluded. This suggests that networks have not really evolved in the system.

Although a real change did not occur in the system, relations could improve in the future as a result of a new alliance emerging on the construction of the offshore harbor between the Venice Municipality, the Venice Water Authority, and the Port Authority. Revealing a smart, strategic reorientation of governmental and private organizations, this alliance seems to be blowing off the historical opposition about the storm surge barriers. The memory of past disputes that these leaders carry along, however, could make them suspicious with regard to new infrastructural works to be carried out in the lagoon.

\section{LINKING LEARNING AND THE IMPLEMENTATION/NONIMPLEMENTATION OF THE ADAPTIVE COMANAGEMENT PRESCRIPTIONS}

In our opinion, the degree to which the prescriptions on polycentricity and participation are followed bears most of the responsibility for the relatively low learning levels we have found (Table 2). The management system of the lagoon, although fragmented to a large degree, has clearly not been 
Table 2. Adaptive comanagement, learning, and connections between the two in the Venice system

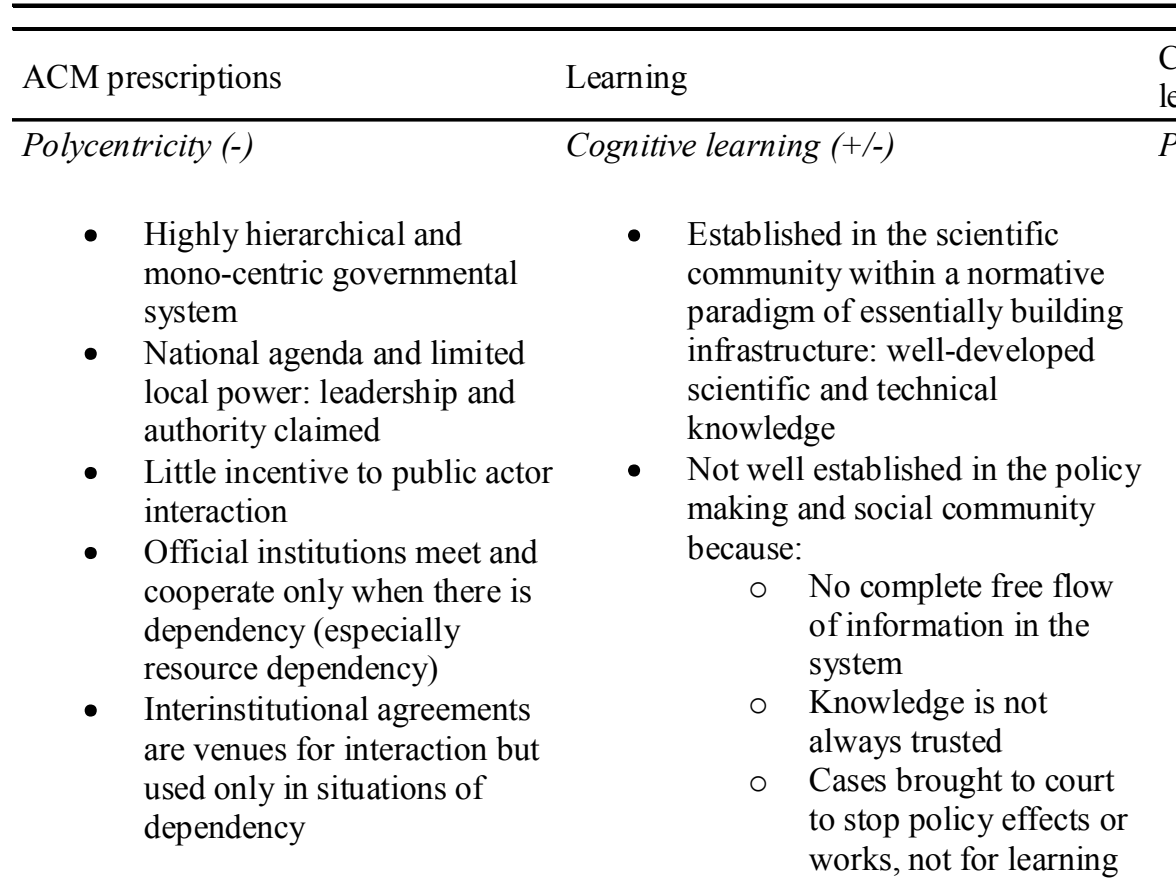

Participation (-)

\section{Normative learning (-)}

- No tradition of participation, and decision making culture is not favorable to it, although EU regulations changed this somewhat

- Participation as tokenism (Arnstein 1969): public is informed and consulted but there is no follow-up, no mechanism to integrate public knowledge

- Limited venue for participation generates frustration that turns into court cases

- Public is not organized: environmental groups and other groups often act individually

Experimentation (+/-)

- Experimentation as research methodology has led to improvements in water and court
Connections between ACM and learning

Polycentricity and learning

- Hierarchical mono-centric structure leads to overlooking of interdependency; opportunities for interaction and cooperation are limited. This leads to limited relational learning

- Existence of coalitions that are more influential than others, a national agenda with a narrow mandate, closed networks hamper relational learning because there is no interest in meeting among actors

- Lack of polycentricity leads to no reflection and no change of perspectives therefore no normative learning

\section{Participation and learning}

- Not well established in the scientific, policy making, and social community because:

- No complete free flow of information in the system

- Knowledge is not always trusted

- Disputes brought to

- Institutional memory may be an obstacle to change

- Shift in policy agenda from physical and environmental protection to economic development is opportunistic because it does not bring new ideas and values but reuses old ideas to keep the system working

Relational learning (+/-)

- Not well established in the scientific, policy making, and
- The frustration generated by the low level of participation does not incentivize relational and normative learning

- Going to court to suspend policy effects or works is a sign of unwillingness to all forms of learning

- Because of limited flow of information in the system, cognitive learning of societal actors is low

\section{Experimentation and learning}

- Experimentation taking place within normative paradigm allows cognitive learning but not normative and relational learning

- Experiments do not serve as boundary objects to draw multiple stakeholders to the 
environmental

management(e.g.,

morphological restoration, mobile barriers)

- Policies are not considered as experiments

- Interpretation and use of scientific knowledge and experiments is often politicized; validity and objectivity are questioned; knowledge is distrusted by actors

\section{Bioregional approach (+/-)}

- Water management at bioregional scale existed in the past through the Venice Water Authority; in the 1970s regions took over responsibilities; EU laws reestablish river basin approach

- Issues of leadership and authority (region vs. Venice Water Authority) hamper the transition to river basin management social community until recent times because of stable governmental system, stable coalitions, and networks that are not open to other actors

- In the last few years change of a number of leaders in public organizations opened windows of opportunity for new coalitions; too soon to tell if it will lead to relational learning

- No complete renovation, some instances of change of position, and no arrival of new people

- Loss of institutional memory with people left debate about the lagoon; there are no mechanisms to challenge values and allow new ideas and people to enter the discussion

- The way experiments are designed and conducted affects how much they are trusted and therefore policy change

\section{Bioregional approach and learning}

- Past experience in river basin management led to building of institutional memory as well as cognitive and relational learning to some extent because actors have worked together and created relations and knowledge

- Institutional memory about past experience of bioregional management limits normative learning because actors tend to act according to the memory they have about the system; agencies that used to rule the system and had knowledge and control of it still tend to act according to those values and beliefs

- Collaboration and learning at the bioregional scale occur if people expect it; if there is memory of one agency having control and knowledge, relational and normative learning cannot improve

- Dealing with existing coalitions and institutions become problematic when new institutions are created over a bioregion

Evaluation scale:

(-) limited; (+/-) to some extent; (+) present 
set up with polycentric governance in mind. The levels of local control over decision processes are too small for that, and the permeating design principle is one of top-down control emphasizing a limited set of goals, essentially building protective infrastructure. There are possibilities for participation but these have not really opened up the system to alternative voices because comments and criticisms are largely ignored. The management community can in this sense be compared to an epistemic community that is closed to outsiders and works on the basis of an established paradigm that must not be challenged. Outsiders, lacking a productive venue for entering debates, resort to the courts, where discussions normally focus on established positions and discrediting the contentions of the opponents (Huitema 2002). The degree of normative learning to emanate from a system like that is low, as was to be expected. The only possible exception to this finding is the higher importance of economic development on the agenda of those who have built the flood safety infrastructure. Here, we should probably be careful about applying the term learning, however, because the developments that have happened look relatively opportunistic and the changed priority of economic development for the Venice Water Authority could easily be interpreted as an organization that has achieved its primary goal, but is looking for a new challenge in which the same approach can be applied. Constructing or expanding a harbor is obviously related to creating a large-scale flood safety infrastructure and fits established lines of working, in the sense that companies that are knowledgeable and experienced in building large-scale infrastructure will try to keep creating the same type of works, so this might actually be an example of a solution looking for a new problem rather than learning. In addition, an adaptive management approach would suggest adopting more flexible, reversible, and adaptable solutions because system's response to management practice is uncertain. However, as a consequence of the new agenda, former opponents are now starting to appreciate each other more, and new coalitions are forged. Here too, the term (relational) learning might be too optimistic because the new coalitions coalesce around established interests and do not emanate necessarily from new insights.

There is a certain level of experimentation going on in the system. This refers to experiments in a literal sense, meaning that physical interventions in the lagoon have taken place, their effects were evaluated thoroughly, and new facts have emerged. These have affected policies to a certain degree, but it does appear that the policy system is lagging in the uptake of these insights. We can say that these experiments have not served as "boundary objects" that were able to draw multiple stakeholders to the debate about the lagoon, and their set up has been largely technocratic rather than participatory. Also, there is no experimentation in the lagoon going on in the sense of "policies as experiments," because the openness to alternative problem definitions or the arguing of alternative policy priorities is very limited as shown by the discussion on the revision of the Special Law. The effect of this on the learning levels is visible, because cognitive learning takes place only among those involved in said experiments and the experiments do not fundamentally challenge policy paradigms (as predicted by Fischer 1995).

Finally, management at the bioregional level is what used to qualify the regime of the Venice lagoon, but with the advent of regional government in Italy, this situation has changed. It is interesting to observe how long the institutional memory from that period has lasted, to both the advantage and disadvantage of the management system. It has been advantageous in the sense that most people working in a fragmented set of water organizations still know their former colleagues well and they can therefore easily reach for each other. The disadvantage is, however, that almost anybody working in the management system purports to provide "the" bioregional view, which means that there is actually contestation of authority. This factor has complicated the implementation of the European Water Framework Directive, which is supposed to work with river basin organizations. In the Venice lagoon, the leading role in this process has not been decided. Effectively there is thus not much of an active, operational basin-wide management approach, but we have not been able to detect much effect on learning levels, except for the cognitive learning that results from the easy exchange of information between former colleagues. As this network of former colleagues becomes less dominant in the various successor organizations, the exchange of information across the basin might become more complicated because information is clearly also a strategic resource for those involved in the management of the lagoon.

Against this background, we conclude that in general the water and environmental governance system in the Venice lagoon exhibits limited implementation of the ACM prescriptions. This has the consequence of a low level of learning in the scientific, policy making, and civic communities. As predicted by governance scholars (e.g., Fischer 1995), cognitive learning in the scientific community is the only exception. As long as shared paradigm and experimental design is not questioned scientific knowledge and management practices keep improving.

\section{DISCUSSION}

The case study of Venice brings to light at least four main points of discussion in connection with the evolving debate on adaptive governance, and linked to that, points to the salience of certain questions for future research. First, the case study presented here offers the opportunity to reflect on the relative importance of the typical prescriptions that are contained in the ACM literature with respect to the key variable of learning (Lee 1999). The case suggests that 
especially public participation and polycentricity are important and that the two can also be connected. Limited opportunities for interaction can in fact be explained not only by a lack of tradition of public participation but also by the existence of a stable, centralized governance system that keep actors disconnected and suspicious. This affects the level of learning in the system and makes it difficult to design policy experiments because scientists and policy makers need to engage in a more elaborate and productive interplay for that to happen (Walters and Holling 1990). Learning then can relatively easily be constrained to the cognitive level, and be made compatible with existing paradigms, thus limiting the opportunity for research experiments to function as boundary objects. We are less certain how to interpret our case study when it comes to the importance of the bioregional approach for learning. Our analysis does confirm the political nature of organizational realignment, but above all it shows that in a situation in which multiple organizations claim to be working on the river basin scale, competition can ensue and such competition can seriously hinder learning.

Related to that is our second main observation on the role of institutional memory. The literature on resilience and adaptive governance tends to discuss memory in a rather positive vein, because memory is treated as a repository for lessons learned. Memory helps prevent making the same mistakes, and in cases where institutions collapse, memory helps bring them back up to functionality. Such memory is held by the people who have worked with the institutional arrangements, and the longer their experience with such arrangements, the more likely it is that they hold valuable memories. However, the case of the Venice lagoon shows that institutional memory can also be a limiting factor to learning. Policy makers who used to manage a large water basin have been resisting the re-establishment of a river basin governmental setting unless this would reassert their authority. Policy learning is clearly hampered by policy makers' values and beliefs, which are rooted on memories of the times their organizations had control over a wide bioregion. However, because this bioregional organization has been split up and personnel divided over a range of new organizations, there is suddenly a range of competing organizations, who all want to operate on the bioregional scale. This raises questions about the normative value of institutional memory in the context of ACM. It would appear that whether institutional memory is good or bad depends on people's values and beliefs about past actions and governance experiences.

For our third point, we would like to turn the reader's attention to a paradox. Hierarchies are supposed to avoid ineffectiveness of horizontal decision structures, which typically lack clear lines of responsibility and authoritative control. Polycentric governance literature has pointed to the key role of leaders to overcome these problems because they can build trust, manage conflict, link actors, initiate partnerships, mobilize support for change, generate knowledge, and develop and communicate visions of ecosystems management (Folke et al. 2005). The Venice system is hierarchically constructed. However, we see competition for responsibility and authority that erodes relational learning and does not favor the emergence of a real leadership. The institutional stalemate that emanates from this situation is hampering the establishment of a river basin management authority according to the European Water Framework Directive. Therefore, in this case hierarchies are both ineffective and an obstacle to change.

The fourth point relates to more general considerations about the applicability of ACM as a normative approach in variegating circumstances. In our study we found the ACM to be helpful for diagnosing a given governance system, i.e., to identify salient features and to understand the basic character of a situation (Young 2007). However, we advocate the relative value of following the ACM. Our case study material does underline the need to investigate more fundamental attributes as precondition for the ACM to take place and be effective and in particular we would like to raise questions about the basic social and cultural requirements for ACM to take place and be successful. The ACM framework might assume certain social and cultural contexts that are not present everywhere. Making these conditions explicit would allow prioritizing actions for ACM successful implementation. Focusing, for example, on policy change needed to make the governance system more polycentric would make no sense if the conditions to make that policy change happen are not there.

The Venice lagoon case study is emblematic of this need to identify and address the fundamental attributes that make or break ACM success. In the Venice case, a fundamental lack of trust among actors proved to be reason for limited communication and sharing of knowledge, and insufficient institutional cooperation that turned into insufficient learning in all societal groups. The Special Law regime is at least partly responsible for this situation because it has created a centralized, hierarchical governmental system that has kept actors disconnected. Actors in Venice have developed resentment and mistrust for each other, and stable but dysfunctional patterns of interaction have developed from these feelings. The relations between the actors have crystallized in closed coalitions and networks that make policy change difficult. In all, there is a serious lack of bridging social capital (Putnam 1994) that could help traverse these divides. However, there is little interest in developing such capital, as is demonstrated by the halfhearted attempts at participation. As Putnam (1994) has shown, there is a strong and persistent relation between levels of social capital on the one hand and governance patterns on the other, with low levels of social capital leading to several pathologies. The question is then 
how to break such a situation open. Insights on transitions in water management published in this journal (Meijerink and Huitema 2010) suggest that one avenue through which such changes occur is through changes in leadership. From this perspective, it is disappointing that the leadership changes that have occurred in Venice in the past few years have involved the same people that were already in leading positions. New opportunities of this sort may take a long time to open up again because the political system in the Venice region is traditionally rather stable.

\section{CONCLUSIONS}

In this paper we analyzed the level of implementation of four typical ACM prescriptions, polycentricity, participation, experimentation, and bioregional approach, and we investigated the degree of cognitive, normative, and relational learning taking place in a complex social-ecological system, i.e., the Venice lagoon in Italy. We analyzed the connections between implementation of the prescriptions and learning. Our ultimate goal was to identify avenues for improvement in the governance of the Venice system. The main conclusion of this study is that in the Venice system the existence of the Special Law inhibits participation and real polycentricity, makes it difficult to change policy in accordance with experimental results, and makes it difficult to deal with problems at the bioregional scale. As a consequence, learning is restricted to environmental management practices whereas networks, values, and beliefs hardly evolve in the region.

The findings and the discussion of this study lead to one concluding observation that is relevant in terms of prospects for change in the Venice system. In our study we identified a number of sources of change in Venice, e.g., the Water Framework Directive, the new morphological restoration plan, the regional and local elections, and the substitution of agency directors, that so far have failed to support an ACM approach mainly because the learning that emanates from them is instrumental to a greater extent. To support change in a more adaptive fashion, a condition that appears to be very important at present is improving relational learning at all societal levels. This calls for an effort to create increasing opportunities for interactions between public actors and societal stakeholders, and among public actors themselves and societal stakeholders as a group. Before that, to make interactions possible, people have to acknowledge the interdependence of all segments of public policy and that the democratization of public decision making can no longer be ignored. This process will require a long time and the engagement of all relevant actors in Venice.

Responses to this article can be read online at: http://www.ecologyandsociety.org/vol17/iss2/art19/ responses/

\section{Acknowledgments:}

The authors gratefully acknowledge receiving support for their work from the Ufficio di Piano for the Safeguarding of Venice, the Ca' Foscari University of Venice and the Dutch Knowledge for Climate Programme.

\section{LITERATURE CITED}

Armitage, D. R., F. Berkes, and N. Doubleday, editors. 2007. Adaptive co-management: collaboration, learning, and multilevel governance. University of British Columbia Press, Vancouver, British Columbia, Canada.

Arnstein, S. 1969. A ladder of citizen participation. Journal of the American Planning Association 35(4):216-224. http://d x.doi.org/10.1080/01944366908977225

Bennett, C. J., and M. Howlett. 1992. The lessons of learning: reconciling theories of policy learning and policy change. Policy Sciences 25(3):275-294. http://dx.doi.org/10.1007/BF $\underline{00138786}$

Berkes, F., and C. Folke, editors. 1998. Linking social and ecological systems: management practices and social mechanisms for building resilience. Cambridge University Press, Cambridge, UK.

Coenen, F. H. J. M., D. Huitema, and L. J. O' Toole, editors. 1998. Participation and the quality of environmental decisionmaking. Kluwer Academic, Dordrecht, The Netherlands.

Dente, B., C. Griggio, A. Mariotto, and C. Pacchi. 2001. Governing the sustainable development of Venice: element of the institutional planning procedure. Pages 227-262 in I. Musu, editor. Sustainable Venice: suggestions for the future. Kluwer Academic, Dordrecht, The Netherlands.

Dietz, T., E. Ostrom, and P. C. Stern. 2003. The struggle to govern the commons. Science 302(5652):1907-1912. http://d x.doi.org/10.1126/science.1091015

Dryzek, J. S. 1987. Rational ecology: environment and political economy. Basil Blackwell, New York, New York, USA.

Fischer, F. 1995. Evaluating public policy. Nelson Hall, Chicago, Illinois, USA.

Folke, C., T. Hahn, P. Olsson, and J. Norberg. 2005. Adaptive governance of social-ecological systems. Annual Review of Environment and Resources 30:441-473. http://dx.doi.org/10 .1146/annurev.energy.30.050504.144511

Gibson, C. C., E. Ostrom, and T. K. Ahn. 1998. Scaling issues in the social sciences. IHDP Working Paper No. 1. International Human Dimensions Program, Bonn, Germany. [online] URL: http://hdl.handle.net/10535/4280 
Giupponi, C., F. Brochier, and J. C. Sors. 2001. Integrated coastal zone management in the Venice area: potentials of the integrated participatory management approach. FEEM Working Paper No. 99.2001. Fondazione Eni Enrico Mattei, Milan, Italy. http://dx.doi.org/10.2139/ssrn.293791

Granovetter, M. 1983. The strength of weak ties: a network theory revisited. Sociological Theory 1(1):201-233. http://dx. doi.org/10.2307/202051

Greenberg, D. H., D. Linksz, and M. Mandell. 2003. Social experimentation and public policymaking. Urban Institute, Washington, D.C., USA.

Gunderson, L. H., and C. S. Holling, editors. 2002. Panarchy: understanding transformations in human and natural systems. Island Press, Washington, D.C., USA.

Haas, P. M. 1992. Introduction: epistemic communities and international policy coordination. International Organization 46(1):1-35. http://dx.doi.org/10.1017/S0020818300001442

Hall, P. A. 1993. Policy paradigms, social learning, and the state: the case of economic policymaking in Britain. Comparative Politics 25(3):275-296. http://dx.doi.org/10.23 $\underline{07 / 422246}$

Haug, C., D. Huitema, and I. Wenzler. 2011. Learning through games? Evaluating the learning effect of a policy exercise on European climate policy. Technological Forecasting and Social Change 78(6):968-981. http://dx.doi. org/10.1016/j.techfore.2010.12.001

Huitema, D. 2002. Hazardous decisions: hazardous waste siting in the UK, the Netherlands, and Canada: institutions and discourses. Kluwer Academic, Dordrecht, The Netherlands.

Huitema, D., C. Cornelisse, and B. Ottow. 2010. Is the jury still out? Toward greater insight in policy learning in participatory decision processes - the case of Dutch citizens' juries on water management in the Rhine Basin. Ecology and Society 15(1): 16. [online] URL: http://www.ecologyandsociety. org/vol15/iss1/art16/

Huitema, D., E. Mostert, W. Egas, S. Moellenkamp, C. PahlWostl, and R. Yalcin. 2009. Adaptive water governance: assessing the institutional prescriptions of adaptive (co-) management from a governance perspective and defining a research agenda. Ecology and Society 14(1): 26. [online] URL: http://www.ecologyandsociety.org/vol14/iss1/art26/

Huitema, D., and E. Turnhout. 2009. Working at the sciencepolicy interface: a discursive analysis of boundary work at the Netherlands Environmental Assessment Agency. Environmental Politics 18(4):576-594. http://dx.doi.org/10.1 $\underline{080 / 09644010903007427}$
Huysseune, M. 2003. Institutions and their impact on social capital and civic culture: the case of Italy. Pages 211-231 in M. Hooghe and D. Stolle, editors. Generating social capital. Civil society and institutions in comparative perspective. Palgrave Macmillan, New York, New York, USA.

Imperial, M. T. 2005. Collaboration and performance management in network settings: lessons from three watershed governance efforts. Pages 380-424 in J. M. Kamensky and A. Morales, editors. Managing for results 2005. Rowman and Littlefield, Oxford, UK.

Imperial, M. T., and T. Hennessey. 1999. Environmental governance in watersheds: collaboration, public value, and accountability. Paper presented at the 21st Annual Research Conference of the Association for Public Policy Analysis and Management, 4-6 November, 1999, Washington, D.C., USA. [online] URL: http://people.uncw.edu/imperialm/Instructor/papers/ Imperial_APPAM_99.pdf

Karkkainen, B. C. 2004. Post-sovereign environmental governance. Global Environmental Politics 4(1):72-96. http:/ /dx.doi.org/10.1162/152638004773730220

Keating, M. 1997. The invention of regions: political restructuring and territorial government in Western Europe. Environment and Planning C-Government and Policy 15 (4):383-398. http://dx.doi.org/10.1068/c150383

Lee, K. N. 1999. Appraising adaptive management. Conservation Ecology 3(2): 3. [online] URL: http://www.con secol.org/vol3/iss $2 /$ art3/

Lejano, R. P., and H. Ingram. 2009. Collaborative networks and new ways of knowing. Environmental Science \& Policy 12(6):653-662. http://dx.doi.org/10.1016/j.envsci.2008.09.005

Mack Smith, D. 1997. Modern Italy: a political history. University of Michigan Press, Ann Arbor, Michigan, USA.

McCombs, M. 2005. A look at agenda-setting: past, present and future. Journalism Studies 6(4):543-557. http://dx.doi.org $\underline{110.1080 / 14616700500250438}$

Meijerink, S., and D. Huitema. 2010. Policy entrepreneurs and change strategies: lessons from sixteen case studies of water transitions around the globe. Ecology and Society 15(2): 21. [online] URL: http://www.ecologyandsociety.org/voll5/iss2/ art21/

Mencini, G. 2010. Una bozza che scontenta. Molte polemiche sul testo della nuova legge speciale per la città presentata dal ministro Brunetta. Terra, Quotidiano di informazione, 16 November.

Moberg, F., and V. Galaz. 2005. Resilience: going from conventional to adaptive freshwater management for human 
and ecosystem compatibility. Swedish Water House Policy Brief No. 3, Stockholm, Sweden.

Mostert, E., C. Pahl-Wostl, Y. Rees, B. Searle, D. Tàbara, and J. Tippett. 2007. Social learning in European river-basin management: barriers and fostering mechanisms from 10 river basins. Ecology and Society 12(1): 19. [online] URL: http://www.ecologyandsociety.org/vol12/iss1/art19/

Olsson, P., C. Folke, and F. Berkes. 2004. Adaptive comanagement for building resilience in social-ecological systems. Environmental Management 34(1):75-90. http://dx. doi.org/10.1007/s00267-003-0101-7

Olsson, P., L. H. Gunderson, S. R. Carpenter, P. Ryan, L. Lebel, C. Folke, and C. S. Holling. 2006. Shooting the rapids: navigating transitions to adaptive governance of socialecological systems. Ecology and Society 11(1): 18. [online] URL: http://www.ecologyandsociety.org/vol11/iss1/art18/

Ostrom, E. 2005. Understanding institutional diversity. Princeton University Press, Princeton, New Jersey, USA.

Ostrom, V., C. M. Tiebout, and R. Warren. 1961. The organization of government in metropolitan areas: a theoretical inquiry. American Political Science Review 55:831-842. http://dx.doi.org/10.2307/1952530

Pahl-Wostl, C. 2006. The importance of social learning in restoring the multifunctionality of rivers and floodplains. Ecology and Society 11(1): 10. [online] URL: http://www.ec ologyandsociety.org/vol11/iss1/art10/

Perrow, C. 1999. Normal accidents: living with high-risk technologies. Princeton University Press, Princeton, New Jersey, USA.

Putnam, R. 1994. Making democracy work: civic traditions in modern Italy. Princeton University Press, Princeton, New Jersey, USA.

Richter, B. D., R. Mathews, D. L. Harrison, and R. Wigington. 2003. Ecologically sustainable water management: managing river flows for ecological integrity. Ecological Applications 13:206-224. http://dx.doi.org/10.1890/1051-0761(2003)013[0206: ESWMMR]2.0.CO;2

Ridder, D., E. Mostert, and H. A. Wolters. 2005. Learning together to manage together: improving participation in water management. HarmoniCOP final report. University of Osnabrück, Institute of Environmental Systems Research, Osnabrück, Germany. [online] URL: http://www.harmonicop. uos.de/handbook.php

Rusconi, A. 2002. Difesa del suolo, i ruoli e i compiti dell'autorità di bacino nell'esercizio della delega. Cinque Fiumi - Rivista quadrimestrale dell'Autorità di Bacino dei fiumi Isonzo, Tagliamento, Piave, Brenta-Bacchiglione 1:4-9. [online] URL: http://www.adbve.it/Documenti/cinquefiumi/5 FIUMIweb.pdf

Sabatier, P. A. 1988. An advocacy coalition framework of policy change and the role of policy-oriented learning therein. Policy Sciences 21(2-3):129-168. http://dx.doi.org/10.1007/B F00136406

Sabatier, P. A. 1998. The advocacy coalition framework: revisions and relevance for Europe. Journal of European Public Policy 5(1):98-130. http://dx.doi.org/10.1080/1350176 $\underline{8880000051}$

Schlager, E., and W. Blomquist. 2000. Local communities, policy prescriptions, and watershed management in Arizona, California, and Colorado. Constituting the commons: crafting sustainable commons in the new millenium, the Eighth Biennial Conference of the International Association for the Study of Common Property , 31 May-4 June, 2000, Bloomington, Indiana, USA. [online] URL: http://dlc.dlib.ind iana.edu/dlc/handle/10535/2133

Skelcher, C. 2005. Jurisdictional integrity, polycentrism, and the design of democratic governance. Governance 18 (1):89-110. http://dx.doi.org/10.1111/j.1468-0491.2004.00267. $\underline{\mathrm{X}}$

Swartling, A. G., and M. Nilsson. 2007. Social learning and EPI: communicative governance in Swedish climate policy formation. EPIGOV Paper No. 12. Ecologic Institute for International and European Environmental Policy, Berlin, Germany. [online] URL: http://ecologic.eu/projekte/epigov/d ocuments/EPIGOV_paper_12_swartling_nilsson.pdf

Ufficio di Piano. 2010. Legislazione speciale per Venezia. Attività di salvaguardia. Quadro finanziario e delle realizzazioni fisiche. Aggiornamento al 31.12.2009. Ufficio di Piano, Venezia, Italy. [online] URL: http://www.magisacque. it/uff piano/finanziamenti_salvaguardia/rapporto finanziame nti_salvaguardia_2010.pdf

Walters, C. 1997. Challenges in adaptive management of riparian and coastal ecosystems. Conservation Ecology 1(2): 1. [online] URL: http://www.consecol.org/vol1/iss2/art1/

Walters, C., and C. S. Holling. 1990. Large-scale management experiments and learning by doing. Ecology 17(6):2060-2068. http://dx.doi.org/10.2307/1938620

Wanta, W. 1997. The public and the national agenda: how people learn about important issues. Lawrence Erlbaum Associates, Mahwah, New Jersey, USA.

Webler, T., H. Kastenholz, and O. Renn. 1995. Public participation in impact assessment: a social learning 
perspective. Environmental Impact Assessment Review 15 (5):443-464. http://dx.doi.org/10.1016/0195-9255(95)00043E

Wondolleck, J. M., and S. L. Yaffee. 2000. Making collaboration work: lessons from innovation in natural resource management. Island Press, Washington, D.C., USA.

Young, O. R. 2002. The institutional dimensions of environmental change. Fit, interplay and scale. MIT Press, Cambridge, Massachusetts, USA.

Young, O. R. 2007. Designing environmental governance systems: the diagnostic method. Keynote at IDGEC Synthesis Conference, Bali 2006. Summary published in IHDP Newsletter 1:9-11. [online] URL: http://www.ihdp.unu.edu/file/ get $/ 7177$ 